\title{
Gold and not so real gold in Medieval treatises
}

\author{
Srebrenka Bogović-Zeskoski \\ In Restauro Conservart Inc., 345 Melrose Av., Toronto, Ont. M5M1Z5, Canada; \\ Croatian Conservation Institute - Hrvatski Restauratorski Zavod, UI. Nike Grškovića 23, 10000, Zagreb, Croatia \\ fineartinfo@rogers.com
}

\begin{abstract}
The aim of this study is to evidence diverse materials and processes used by artisans (and alchemists) required to synthesize a visually viable replacement for gold. The emphasis of the research is upon the production of mosaic gold or porporina, a pigment that has survived into modern times, which was used as ink and as paint. Base metals, mostly tin, but also alloys were used both into foils coated with glazes and varnishes and as pigment. The research focuses upon recipes documented in treatises dating from Antiquity to the late Medieval period (ca. 1500) and an attempt is made to answer two questions. In the first place, why was there a need for a surrogate? Secondly, why are there so few tangible examples detected on surviving artifacts? In conclusion, an argument is offered pointing out that, although much can be learned by scientific examination of artifacts, textual analysis is equally important and necessary to unravel mysteries of ancient technologies.
\end{abstract}

\section{Ouro e imitações de ouro nos tratados medievais}

\section{Resumo}

O objectivo deste estudo é mostrar os diversos materiais e processos usados pelos artesãos (e alquimistas) na procura de um adequado substituto do ouro. A pesquisa é direccionada especialmente para a produção de ouro-músico ou purpurina, um pigmento que se manteve até à actualidade e que foi usado sobretudo como tinta e como pigmento. Metais comuns, particularmente estanho, assim como ligas, foram usados quer como folhas sobre as quais eram aplicadas velaturas e vernizes, quer como pigmento. A pesquisa incide sobre as receitas registadas nos tratados da Antiguidade até ao período medieval (ca. 1500) e é feita uma tentativa de responder a duas questões. Em primeiro lugar, a que se deveu a necessidade de uma imitação do ouro? Depois, por que é que sobreviveram tão poucos exemplos? Em conclusão, é referido que, ainda que muito se possa aprender através da análise científica das obras, a análise documental é igualmente importante e necessária para se esclarecer os mistérios das antigas tecnologias.

\section{Keywords}

Mosaic gold

Glaze

Porporina

Chrysography

Amalgam

Medieval treatises

\section{Palavras-chave}

Ouro-músico

Velatura

Purpurina

Crisografia

Amálgama

Tratados medievais

ISSN 2182-9942 


\section{Introduction}

Base metals such as tin, copper even iron and alloys like brass and bronze, are recurrently mentioned in various treatises as a replacement for gold, or as its surrogate. Most recipes claim that with appropriate manipulation the substitute would seem to the observer just like real gold ("ut littere videantur de auro") [1] and that even "artisans would not be able to detect the difference" [2].

There are two basic ways to doctor pure gold. One is to extend it; another is to make an alloy with base metals which take aspects of gold but do not contain any portion of the noble material. An entirely different technique involves shiny/reflective metals such as tin or silver to be altered by the application of diverse yellow varnishes and glazes. Combined, the reflective quality of these metals and the proper color of surface finish make them appear as a genuine gold leaf.

Several reasons can be singled out and each most likely contributed to the apparent need for a gold substitute: scarcity, economics, or even deceit.

By the Middle Ages, European deposits of gold were dwindling or were exhausted [3]. Most of the European gold was obtained by exploiting alluvial deposits, limited mining, trade, and war lootings or by re-melting existing objects. Alluvial deposits are already mentioned by Diodorus Siculus (ca. 60-30 BC) who described Gaul's rivers as "full of gold dust" [4] and later on by Theophilus [5], under the heading: "De auro arenario", regarding gold that was found on the banks of the river Rhine. The authorship, date and purpose of Schedula of Theophilus are still contentious, but the early 12 th century is a generally accepted date [5]. The few gold mines that existed were often abandoned because of rising waters which were at that time difficult to control $[6,7]$. The most famous mine surviving into modern times was situated near the Kremnica mountains (in today's Slovakia). The town of Kremnica was also known during the Middle Ages for minting the famous ducat coin. The demand for gold was augmented by imports from Arabia, Egypt (i.e. Nubia) and from as far away as India [8].

One of the plausible requirements to replace gold with a reasonable facsimile was certainly economics. Both Theophilus [5] and Audemar (De Coloribus Faciendis, ca. 13th-14th centuries) [1] preface one of their recipes with: "if you have neither of gold nor silver" ("si neutrum habeas scilicetnec aurum nec argentums") and recommend tin as a satisfactory substitute ("stanum purissimum"). In recipe no. 205 Audemar is even more explicit, suggesting the choice of tin "on account of the price of gold" [1]. Merrifield indicates that when the parties were unable or unwilling to pay for gold, "tin foil yellowed with varnish was especially effective for murals where it would be seen at some distance". Cennini shares the same opinion $[1,9]$. Documents regarding the decoration of the church of S. Jacopo in Pistoia (late 13th century) mention some 37 pieces of tin, rather than gold leaf, used to conjure the same gleaming effect, but at a much reduced expense [1].
Tin as well as silver were especially suitable because of their high reflective quality. Audemar notices that the satisfactory appearance of tin in lieu of gold is due to its great brilliance [1]. Gold and costly pigments such as lapis lazuli invariably formed a separate part of a given contract, specifying where they were to be applied and in what quantity in order to safeguard patrons from substitutions of lesser value [10].

A number of treatises also address the quality control of gold and instructions are given on how to test its purity. The author(s) of the Leyden papyrus, of late 3rd century suggest that, if gold is heated and becomes white, it contains silver and, if it becomes rougher and harder, it contains copper and tin, but should it blacken, the admixture is lead [2]. In the Tagernsee ms. (ca. 11th century), recipe no.148, among others, gives instructions for testing gold ("Eine goldprobe") and no.149 for testing silver ("Probacio argenti si sit purum") [11]. Test for gold's purity was even mentioned in the Bible, Zachariah (13:19): "And I will put this third into the fire, and refine them as one refines silver, and test them as gold is tested". The test for purity was likewise necessary to monitor an alloy's composition as a prerequisite for a successful chemical fusion, while at the same time discouraging forgery. But embezzlement is as old as mankind and ancient artisans were no exception. Pliny mentions that very high-priced cinnabar was corrupted with goat's blood or with crushed service-berries [12] and Eraclius (De Coloribus et Artibus Romanorum, LI.241), "on trying azure", gives instructions on how to determine that it is not adulterated [1]. Several recipes in the Leyden ms. and in the $600 \mathrm{AD}$ Mappae Clavicula [13] deal with how to double the weight of gold, so there is nothing to prevent us from believing that some true gilding was of a lesser purity or contained no gold at all.

\section{State of research regarding gold substitutes}

Scholarship on gilding sporadically considers the existence of base metals as a replacement for gold, often only in passim. Daniel V. Thompson, an authority on medieval painting techniques, in his seminal textbook laments: "I have only once in my life been quite sure that I was looking at mosaic gold in a medieval work" [14]. He cites ms. Palatina 951, dating from the 14th century (Biblioteca Nazionale, Florence), as having some of its capital letters executed in faux gold and its folio $125 \mathrm{v}$ gives instructions on how to prepare it. Listing examples of fake gold that have been identified up to now needs to be the subject of further research. Just to corroborate the use of the so-called mosaic gold, or surrogate gold, it was for example identified on a polychrome stone statue of Santa Ana dating to the 13th century in Santa Maria de la Real (Sasamon, Spain). A yellow-reddish pigment on the hem of the Saint's cape was a tin (IV) sulfide identified by Raman spectroscopy and confirmed by SEM [15]. The 
mosaic gold was admixed with red lead and therefore its detection was not obvious without the use of sophisticated analytical tools. It is important to note for future reference that detecting or overlooking the presence of mosaic gold could be caused by the material's visual camouflage. This is especially plausible when it is added to other pigments.

The lack of scholarship regarding gold substitutes can also be attributed to the very nature of artisanal treatises. Until relatively recently they were considered as simple workshop instructions/notations or alchemical nonsense of a limited scientific, literary or art historical significance and therefore of doubtful research value [16]. Their credibility was not helped by such instructions as "always stirring it with dog's foot that has its hair and wool" [17]. Was this a preposterous suggestion? Once tested, these and other implements/processes were proven to have a very sound application and cannot any longer be dismissed as nonsensical. It was experimentally demonstrated that "the fuzzy dog's foot" is essential to combine two very immiscible materials such as liquid mercury and powdered sulfur, two main ingredients in making mosaic gold [17]. There are recipes where, for example, dragon's blood is properly identified as a resin, a product of the plant draco (Dracaena draco), while others repeat the proverbial battle between a dragon and the elephant already recorded by Pliny [12]. Similarly, instructions listed in the Schedula, mostly based on Theophilus' solid understanding of metals and metallurgy, contain a rather atypical recipe for Spanish gold, requiring basilisk powder and human blood [5]. Hawthorne \& Smith rightly rehabilitate Theophilus, pointing out that this odd recipe received far more attention than it deserved. Theophilus was possibly transcribing symbolic language of alchemy without great understanding or even interest. Most likely his so-called Spanish gold refers to brass or to a cementing process which enabled a deposit of gold onto an auriferous copper [18]. Alcherius' vermes auri (Experimenta de Coloribus, 14th century) after a lengthy burial would be found in aged bull's brains (cerebrum tauri), were considered precious, and needed to be "carefully preserved"; falls within the same category [1]. There are similarly implausible ingredients mentioned in Mappae Clavicula, but this manuscript is of a much earlier date and therefore closer to alchemical tradition [13]. Clarke dismisses such relatively rare, odd recipes as Gednakeneexperimente [17]. In other words, they might have been added by a craftsman as a note to try it later, just in case, there might have been some merit to it, or added much later by a general reader who made the notation without any intent to put it to test.

Alongside a chemically sound and fanciful recipes for obtaining surrogate gold there are as many that contain instructions for executing proper gilding (water or mordant), how to purify gold, how to make gold leaves and extolling the beauty of gilded objects.

Explaining the scarcity of examples is probably the most difficult task and any arguments should be seen as pure speculation for now. Gold's allure is as strong today as it was in ancient times. Its monetary, but also its spiritual value made it suitable to be applied to a wide range of objects, but specifically to those with otherworldly or mystical significance [3]. Gold's association with heavenly powers is found in both preChristian and in Christian religions and was deemed an appropriate material to address the gods or to represent the divine [19]. Replacing it with an inferior material could be seen as sacrilegious or even heretical. It therefore stands to reason to speculate that a humbler mosaic gold could be used for objets d'art of lesser significance. Such artifacts, over a period of time, had lower survival chances due to neglect or disregard. It is also possible that artisans far from important centers controlled by royal or ecclesiastical authority were more inclined to use a surrogate metal without facing penalties for ignoring rules either of their respective guilds or of those in power.

\section{Artisanal manuscripts}

Medieval manuscripts such as Theophilus' Schedula, Le Begue's compilation, Cennini's Il Libro dell'Arte and above all the Montpellier Liber Diversarum Arcium (ca. 1430) are but a few pertinent examples of manuals that describe in detail the working methods of medieval artists, a tradition upon which later instruction books relied rather heavily $[1,5,17]$. These manuscripts differ significantly from the early writings by Pliny or Dioscorides [20] as they are clearly based on the authors' direct practical experience and technique. Most of those recipes are more complete regarding ingredients and instructions, now easier to follow. Notations are either directed as manuals to apprentices (indocti) or are recetari for knowledgeable practitioners. In this sense, these compilations should be considered "as the theory of artistic practice, a set of technical rules and standards codified into recipes so art could be taught, learned and exercised" [21]. In turn, their subject matter relied heavily on ancient sources such as the two Leyden and Stockholm papyri, followed by the Lucca codex 490 [22, 23] and Mappae Clavicula of GrecoByzantine origin (but recopied somewhere North of the Alps) [13] and a number of others recently published [17]. Although of a later date and often neglected but still steeped in the Medieval tradition and equally prominent as a manual, the Illuminierbuch (1549), by Boltz von Ruffach [24], also from Northern Europe, must be added to the list.

\section{Gilding of tin leaves and other base metals}

Gilding with base metal foils is very similar to the genuine gilding process. Instead of gold leaves, tin foil (brass, copper etc.) is laid down on a prepared ground. Different mordants are suggested (size, glair, gums, resins, even oil) followed by an application of a yellow 
colored surface coating to impart a gold aspect to the metal leaf. The most frequently mentioned colorants were extracts of plants such as saffron, celedonia, hepatic aloe, the inner bark of pomegranate or verwain mallow. The other organic substance frequently mentioned was gall or bile of various animals: oxen, goat, fish or turtle. Among inorganic colorants, orpiment was used most often, although in rare cases ochre was also added. Ochre, due to its opacity, was possibly an adulterator or extender rather than a color enhancer. A number of recipes call for a mixture of both organic and inorganic ingredients.

In some recipes, this transparent coating is identified as auripetrum or auripigmentum as in recipe no. 202 by Audemar, which calls for Spanish saffron to be distempered in glue or liquid varnish and applied over polished tin [1]. Eraclius (no. XLIV, "De auro petro") lists a whole gamut of ingredients: vesprum ("well dried bark and boiled", but of still of unknown origin), or incaustum, or bark of blackthorn, myrrh, aloe, vernix (sandarac) and "if this is not available", then glassa (amber) [1]. Lucca ms. (no. 80, "Scripto similis auri") [22, 23], likewise lists several ingredients, adding also bile of a river turtle: "Take three drachma of the following: celandine, crushed resin, golden colored gum (gumen auri colores), pure orpiment bile of a turtle (fel testudinis), 5 drachme of Cilician (Turkish) saffron. Good for writing on parchment or paper, or glass, or marble". This recipe is very similar to recipes no. 63 in the Leyden papyrus except that cnecos (safflower) is suggested and a "very bitter bile of a calf". The Montpellier ms. adds to the list the juice of ivy and the blood of a goat (N. 4.37.1C). Another recipe from the same manuscript (2.8.2) introduces several more ingredients: pine resin, genuine hepatic aloe ("if that is not found, horse-aloe"), and dragon's blood, all to be boiled with linseed oil [17]. The term doratura, or vermeil is related to surface coatings but requires some clarification as it can apply to a different processes altogether. Generally it is considered as some type of transparent yellow glaze. However, as Thompson rightly points out, Eraclius' recipe ("De deauratura petulea stagni", no. XIII), is not related to what is generally considered as vermeil [1]. The only way the recipe is relevant to the topic of glazing is the necessity to dip the amalgam/tin plate into a mixture of soot and beer to take on a golden color. On the other hand, Cennini's doratura ("Come si fa stagno dorato") [9] relies likewise on plant material for surface modification. This doratura is akin to a recipe found in the Montpellier ms. which is practically contemporary with Il Libro. In "De confectione dorature" (Montpellier), hepatic aloe, linseed oil and saffron are boiled together and then applied "by hand three times" [17].

\section{Mosaic gold and porporina}

The surrogate gold pigment became known in Europe by the 13th century [7]. Chemically, mosaic gold is a tin disulfide $\left(\mathrm{SnS}_{2}\right)$, or tin (IV) sulfide, which is of a golden- yellow color. Unlike gold, it can be easily ground and thus readily tempered with an assortment of glues, gums, glair and even oil. [1, 2, 9, 14, 17]. To alter gold from a solid metal into a fluid ink to use it for chrysography required milling it into a powder that can be tempered with appropriate medium. Because of its malleability gold could be beaten to leaves of only 50-100 nm thickness but for the very same reason turning it into a fine powder was an arduous task requiring a special mill as described by Theophilus [5, 25]. Le Begue, on the other hand, suggests apothecary mill rather than grinding on porphyry, or to add other substances such as salt or honey to prevent gold particles from re-adhering [1]. A less taxing grinding process was suggested by alchemists where gold is combined with mercury rendering it hard and brittle thus easier to mill $[1,26]$.

Cennino's porporina, also mentioned in the Bolognese ms. (Bib. Universitaria 2861, 15th century) [1] and Brussels ms. (Pierre Le Brun, no. 15,552, dated 1635), is better known in alchemical literature as oro musivo or mosaic gold. Regarding this pigment Thompson cites a number of different names as recorded in various treatises: aurum musaicum or aurum musicum (lat.), oro musaico, oro musivo (it.), or musiff (fr.) and oro de musico (sp. \& portuguese) and Spanish gold [9]. To this list one can add aurum musitum from the Strasburg ms. [27]. The term oro de musico is disputed as it is considered an idiom pertaining to music rather than to illumination and should actually be given as ouro musivo when referring to its use in Spanish and Portuguese texts [28, 29]. Thompson further suggests that the very name, mosaic gold, is contentious and that more study should be conducted regarding its manufacture, use and nomenclature. Considering the date of Thompson's seminal book on Cennini (1933), not much has been accomplished in this field as far as is known to this writer.

Manuscripts of the so-called Books of Secrets group, such as are the Mappae Clavicula and the Compositiones Variae, mention the use of amalgam but neither proposes grinding the alloy to obtain a gold-like pigment. Amalgam is a term used for any compound made with mercury, but mixed with some base metals in presence of sulphur forms an alloy that can have an aspect of gold. The Leyden papyrus, the predecessor of both Lucca and Mappae Clavicula manuscripts, contains recipes that are predominantly concerned with a list of ingredients necessary for fabricating or synthesizing asem, but without instructions on how to do it or mentioning asem's purpose [2]. There are five recipes for asem: 5, 8, $9,11,12$, although not all of them call for mercury and therefore do not form an amalgam. Jensen identifies asem or assemon as a term referring to alloys mostly intended to imitate gold or silver [2]. It is also suggested that in general, alloys were principally an attempt to transform all base metals into gold, not only for pecuniary or aesthetic reasons but because the ultimate endeavor of alchemists was perfection; therefore all metals likewise strive to eventually achieve that state which is attained 
in gold [3]. Assertion that "lead is gold inwardly [...] but lead outwardly" fittingly illustrates this desire [23].

One of the early mentions of what can be considered as a mosaic gold is in Schedula. The recipe no. 48 introduces another term: auro hispanico [5]. However, as already mentioned, this is a very unusual recipe for Theophilus since, generally, most of his writing or copying is based on personal knowledge and is therefore infused with a sound technological foundation.

Although not as precious as gold to fabricate, these surrogate pigments or coatings still required a complex and a laborious process. Bersch [26], a modern-day chemist, lists several formulae for the preparation of mosaic gold which are very similar to early recipes found in the ancient treatises: tin filings, sublimated sulfur (sulphrum vivum) and ammonium chloride (sal ammoniac, salmiac). For some recipes, he also indicates mercury to form an amalgam. Forming amalgams with base metals (tin was the most common, but is not the only one) had its very practical purpose as it promotes a more immediate bonding with sulfur. However mercury was also used to separate gold from its impurities, or if it was not sublimated, to render gold more brittle and therefore easier to grind if fine particles were sought [25].

All the ingredients for mosaic gold were known from Antiquity [30, 31]. KoHung describes as early as the $300 \mathrm{AD}$ the making of stannic sulfide [32], which Europeans much later transformed into a yellow-gold pigment called purpurino or purpurinus. For this process to be successful, the temperature level was critical; it had to be low at first, to be gradually increased to a dark red heat and maintained for a considerable time (half a day is often suggested). The degree of heat was regulated by the presence of ammonium chloride [30, 31]. The container (matras or ampulla) was left to cool off and it was usually broken to retrieve its contents. The yellowish pigment was found as a deposit at the bottom of the flask, or as crystalline scales on the vessel's walls. Certain variations to the basic recipe are recorded. The Bolognese ms. no. 168 [1] probably gives the most thorough and well outlined process, explaining how to achieve a good amalgam, at what point to add sulfur and sal ammoniac, how long it should be exposed to heat and finally advises to temper it with gum water and to store it in a horn; "write and the letters will appear fine and shining". The Montpellier ms. devotes a number of recipes to the modification of base metals [17]. Of these, gilding eramen (copper or copper alloy, no. 4.1.1) is not real mosaic gold as it uses also genuine gold leaves, though this was not an unusual practice. Iron is gilded in the same way, as is outlined in recipes for silver and auricalcum (nos. 4.2.1, 4.3.1, 4.4.1) [17]. The recipe for gilding an auricalcum ring seems to be derived from Mappae clavicula.

A 17th century formula by Knuckel [33] mixes bismuth and tin for similar results. The Brussels ms. no.13 likewise synthesizes purpurino from an amalgam of brass to obtain "jaune qui imite la colueur d'or" [1]. Bolognese ms. recipes in chapter VI (no. 141, 142, 143, 144 and
145) pretty well follow the established ingredients except that no. 141 omits ammonium chloride [1]. Recipe 154 does not suggest to use any heat (was it obvious and thus omitted?); instead, tin filings are mixed with mercury "to be all well pounded with moistened gum Arabic" [1]. This recipe is similar to Eraclius no. XIII [1], "Of gilding tin foil", which possibly provides a better clue as from where the golden color is obtained: tin plate is dipped into a mixture of beer combined with soot and "it will look like gold". Merrifield suggests that soot was most likely made from birch wood, usually the main ingredient in making warm golden colored bistre ink [1]. And, finally, recipe no. 146 hardly makes any sense at all except when compared with a similar recipe in Experimenta de coloribus (no.22): from an egg, the white is removed through a small hole and replaced with mercury. The hole is lutted and the egg is placed under the hen for 30 days and a gold color is found. Alcherius enlarges upon the instructions by suggesting to remove the mercury and mix egg yolk with a crystal reduced to a fine powder [1]. This mixture is then used to make the desired design over which, when dry, gold or silver is rubbed onto. Using gritty material to create a tooth over which gold can be rubbed over is also mentioned by Clarke [17].

A manuscript, ms. 1793 (Biblioteca Casanatense, Rome), signed by Simone di Monte Dante de la Zazera, was discovered and transcribed by Wallert [33]. He assigned it to a "particular group of technical art treatises" specifically devoted to manuscript illumination that deal with the preparation of colors, inks and gilding, but are not related to the Mappae Clavicula group. Of interest are a few recipes referring to purpurino also named origno (no. 19). However, these recipes list unusual and possibly erroneous ingredients such as nitric salt instead of sal ammoniac and lead instead of tin. This mixture would hardly produce a yellow-gold color. (Leyden's recipe no.15, on the "Coloration of gold", also mentions salt [2].) Recipe no. 17, "To make purpurina", omits sulfur, an essential ingredient for the fusion. Clarke points out that reworking texts was very common and transcribing them was often divorced from workshop practices, which results in technical inaccuracy [17].

In Alcherius' Experimenta de Coloribus [1] two recipes that refer to purpurina colorem: no. 19 and no. 39 reiterate the process described by Bersch [26]. Tin filings are mixed with hot mercury to which sulfur and sal ammoniac are added. The compound is put in a luted flask with small vents provided. When fumes are no longer discharged from the flask, it is left to cool, subsequently broken and the purpurinus collected. The pigment obtained is then tempered with gum water or frothed egg white (glair). Recipe no. 39 posits that the color obtained is as beautiful as gold ("colorem pulcrum et aurum") and recommends its use on books and parchment ("libris et cartis").

From another recetario that lists a number of recipes mostly from the 15 th to the 17 th century, one is selected as representative of many others (Pal.916 (1455), C113r): 
Fare porporina fine: Take mercury, Roman tin in equal quantities and mix together, let cool. Choose solfo vivo or sulfur in sticks, the most yellow you can find, sal ammoniac in the same quantity, pulverize all that together and add ox dung and put it in a glass vessel (put it on a fire) and when there is no longer any smoke, stir with a stick for two Miserere and then let it cool. Use it to write in silver, tempering with gum [34].

In Medieval recipes, but already noted by Pliny, different substances often come under a same name. Likewise the Leyden papyrus (no. 59) lists talk, "called chalk", to act as a flux; however the substances known to us by that name, talk, a silicate mineral, and chalk, a calcium carbonate would not be able to influence in any way the temperature. Another telling example is Eraclius' no. LIV(245) - "How to make purpurino" (purpurinus color). It refers to the real purple obtained from whelk and not to mosaic gold at all [1]. Flint (i.e. quartz), a stone that emits fire (ignem emittentes), is roasted and then quenched with strong vinegar. Quartz solubility increases with higher temperatures thus it can be reduced to a very fine powder, but its purple color is obviously obtained by adding something named oster [1]. The recipe describes oster as if it were some kind of plant material: "nascitur in insola Cipri" where it grows "cum solis". However the last sentence is straight from Vitruvius [35]: "it solidifies on account of its saltiness". Vitruvius mentions a dye ostrum, extracted from marine shells, in other words the famous source of Tyrian purple obtained from the whelk mollusk. This is but one of a number of examples where the scribe either did not understand the original text, was unaware that a sea shell can render a purple color and readily assumed that in all likelihood the dye was obtained from a plant. The scribe's supposition must have been supported by a recipe immediately following, "Of lakes" (no.LV), which asserts that purple color is made from madder roots, flowers (viola lutea), and, as also mentioned in the subsequent recipe (no. LVI), from the so-called clothlets or bisetum/biseth which Merrifield identifies as Italian pezzette, rags dipped in juices of certain plants that later on release the dye by soaking [1].

Of the three manuscripts consulted, produced North of the Alps, Boltz von Ruffach [24], although of a later date (1549), devotes five entries to mosaic gold ("Aurum musicum zemachen"), also listing similar ingredients except that recipe no. 4 omits mercury. The procedure is almost identical to the Bolognese recipes mentioned above. In the section on Von lybfarben, mosaic gold is again introduced as Aurum musicum, guldene stuck (i.e. gulden, gold coin) and argentum musicum. The mosaic gold, he suggests, can be shaded with cinnober, to which a bit of soot water is added (rousswasser), and reddish pigment (rösslin), which is in keeping with the above mentioned example regarding the robe of the Santa Ana from Santa Maria de la Real. He suggests again that it is possible to write with mosaic gold and that the chrysography should be shaded with Paris red or lac [24].

The Trier Malerbuch (1491) [11] refers to the pigment as aurum musicum (or mussicum) and lists also: tin, mercury, sulfur and salmiac. The manuscript however suggests heating the mixture "eynen gantzen dach" (i.e. the whole day). The Strasburg ms. gives only one recipe for the aurum musitum: "The process I am describing must be kept secret. If you want to make golden writing, procure aurum musitum from the apothecary (nim in der appotek) and grind it with water" [27]. By this time there was a proliferation of the so-called vendecolori i.e. the suppliers of artists' materials [36]. "Take gum Arabic and water and add this to the aurum musitum till they are the same consistency as for rubericks (diki als ein ruberick) write anything you wish with it".

And, finally, one needs to mention that not everybody was enthusiastic about mosaic gold. Cennini was aware that gold has affinity to mercury so he forewarns to be careful as of fire in using mosaic gold "because if there was half a millet seed of quicksilver [...] and that came in contact with gold ground [...] it would be enough to ruin the whole thing" [9]. Curiously then he proceeds to give a recipe for making mosaic gold anyway.

\section{Conclusion}

This research, examining the use of surrogate gold as recorded in various manuscripts, does not pretend to be an exhaustive account regarding the application of these techniques on artifacts dating mostly from the late Mediaeval to the Early Renaissance periods. An increased interest in ancient documents has unearthed a great number of new manuscripts (sometimes just a few, but important folios) significantly contributing to our understanding of various historical materials and processes. Clarke who examined many such treatises mentions some 450-recipe books that survived, many containing workable and fully replicable instructions [17]. It is safe to assume that this number is not final and with intensified research and increased interest more will surface to be studied. Since the publication of his The Art of All Colors, more than 50 additional manuscripts have been identified and it is therefore safe to conclude that the evidence of mosaic gold, porporina, doratura and vermeil among other recipes will increase.

The main intent of this research was to demonstrate that there is much room left for further study on this topic. With time and the use of sophisticated analytical techniques, coupled with awareness and the examination of available textual references, it is likely that a lot more examples will be detected. One can also postulate that the two main reasons for lack of evidence of these materials on surviving artifacts is the tendency of mosaic gold to age by losing its characteristic brilliance and for glazed base metals to lose their coating either through weathering or even through unprofessional or indiscriminate cleaning. 
Bearing this in mind, artifacts from the mentioned periods, and even of a later date, that do not readily appear to have been gilded might still contain evidence of various gold substitutes.

\section{Acknowledgments}

I wish to express my gratitude to my colleague Romana Jagić of the Croatian Conservation Institute in Zagreb for many pertinent points on gilding materials and techniques and for the opportunity of working together on the restoration of a complex Renaissance gilded altar on the island of Šipan, a jewel of the Dubrovnik School. This paper is dedicated to her memory.

\section{References}

1 Merrifield, M. P., Original Treatises Dating From the XIIth to XVIIIth Centuries on the Arts of Painting, 2 vols., John Murray, London (1849) [reprinted as Medieval and Renaissance Treatises on the Arts of Painting: Original Texts with English Translations, Dover Publications Inc., New York (1999)].

2 Caley, E. R., The Leyden and Stockholm Papyri, GrecoEgyptian Documents From the Early 4th Century AD, ed. W. B. Jensen, University of Cincinnati, Cincinnati (2008).

3 Bucklow, S., The Alchemy of Paint, Art, Science and Secrets from the Middle Ages, Marion Boyars, London, New York (2009).

4 Oldfather, C. H., Diodorus of Sicily in Twelve Volumes, book 5, Harvard University Press, Cambridge (1977).

5 Hawthorne, J. G.; Smith C. S., Theophilus, On Divers Arts, The Foremost Medieval Treatises on Painting, Glassmaking and Metalwork, Dover Publications Inc., New York (1979).

6 Neville, A., Mountains of Silver and Rivers of Gold, Oxbow Books, Oxford (2007).

7 Blanchard, I., Mining, Metallurgy and Minting in the Middle Ages, vol. 2, Franz Steiner Verlag, Stuttgart (2001).

8 Forbes, R. J., Studies in Ancient Techniques, vol.8, Leiden, E.J. Brill (1971).

9 Thompson, D. V., The Craftsman's Handbook. "Il Libro dell"Arte". Cennino d'Andrea Cennini, Dover Publications, Inc. (1954).

10 Glasser, H., 'Artists' Contracts of the Early Renaissance', $\mathrm{PhD}$ dissertation, Columbia University, New York (1965).

11 Bartl, A.; Krekel, C.; Lautenschlager, M.; Oltrogge, D., Der 'Liber illuministarum' aus Kloster Tegernsee, Franz Steiner Verlag, Stuttgart (2005).

12 Rackham, H., Pliny, Natural History in Ten Volumes, vol. 9 , Harvard University Press, London, William Heinemann Ltd. (1934).

13 Roosen-Runge, H., Farbgebung und Technik Frühmittelalterlicher Buchmalerei, Studien zu den Traktaten Mappae Clavicula und Heraclius, Deutcher Kunstverlag (1967).

14 Thompson, D. V., The Materials and Techniques of Medieval Painting, Dover Publications Inc., New York (1956).

15 Edwards, H. G. M.; Farwell, D. W.; Newton, E. M.; Perez, F. R.; Villar, S. J., 'Raman spectroscopic studies of a 13th century polychrome statue: identification of a 'forgotten' pigment', Journal of Raman Spectroscopy 31(5) (2000) 407-413, doi:10.1002/1097-4555(200005)31:5<407::AIDJRS530>3.0.CO;2-Y.
16 Warren, L. E., 'Chemistry and chemical arts in ancient Egypy. Part I', Journal of Chemical Education 11(3) (1934) 146-153, doi:10.1021/ed011p146.

17 Clarke, M., Medieval Painters' Materials and Techniques. The Montpellier Liber diversarum arcium, Archetype Publications, London (2011).

18 Dines, I., 'The Theophilus manuscript tradition reconsidered in the light of new manuscript discoveries', in Zwischen Kunsthandwerk und Kunst: Die 'Schedula Diversarum Artium', ed. A. Speer, De Gruyter, Berlin (2014) 3-10, doi:10.1515/9783110334821.3.

19 Janes, D., God and Gold in Late Antiquity, Cambridge University Press, Cambridge (1998).

20 Beck, L., Pedanius Dioscorides of Anazarbus. De Materia Medica, Olms-Weidmann, Hildesheim (2005).

21 Kroustallis, S., 'Los recetarios medievales de tecnologia artistica', in Art Technology - Sources and Methods, ed. S. Kroustallis, J. H. Townsend, E. C. Bruquetas, A. Stijnman and M. San Andres Moya, Archetype Publications, London (2008) 35-41.

22 Johnson, R. P., Compositiones Variae, From Codex 490, Biblioteca Capitolare, Lucca, Italy. An Introductory Study, University of Illinois Press, Urbana (1939).

23 Caffaro, A. Scrivere in oro: Ricettari Medievali d'Arte $e$ Artigianato (Secoli IX-XI). Codici di Lucca e Ivrea, Liguori, Naples (2003).

24 Ruffach, B. Illuminierbuch, Wie Man Allerlei Farben Bereiten, Mischen Und Auftragen Sol (1549), reprinted George D.W. Callwey, Münich (1913).

25 Nutting, J.; Nutall, J. L., 'The malleability of gold', Gold Bulletin 10(1) (1977) 2-8, doi:10.1007/BF03216517.

26 Bersch, J., The Manufacture of Mineral and Lake Pigments, Containing Directions for the Manufacture of All Artificial Artists and Painters Colors, Enamel Colors, Soot and Metallic Pigments, Forgotten Books, London (1901).

27 Borradaile, V. and Borradaile, R., Das Strassburger Manuskript: Handbuch für Malerei des Mittelalters / The Strassburg Manuscript: A Medieval Painter's Handbook, Alec Tiranti, London, (1976).

28 Abrahams, H. J. 'A thirteenth-century Portugese work on manuscript illumination (Il libro de como se fazem as cores', Ambix 26(2), (1979) 93-99, doi:10.1179/amb.1979.26.2.93

29 Cruz, A. J.; Afonso, L. U., 'On the date and contents of a Portuguese medieval technical book on illumination: O livro de como se fazem as cores', Medieval History Journal 11(1) (2008) 1-28, doi:10.1177/097194580701100101.

30 Berthelot, M. Introduction à l'Étude de la Chimie des Anciens et du Moyen-Âge, Steinheil, Paris (1889).

31 Stillman, J. M., The Story of Early Chemistry, Appleton, New York (1924).

32 Needham, J., Science and Civilization in China. Volume 5. Chemistry and Chemical Technology, Cambridge University Press, Cambridge (1974).

33 Wallert, A., 'Libro Secondo de Diversi Colori e Sise da Mettere a Oro: a 15th-century technical treatise on manuscript illumination', in Historical Painting Techniques, Materials, and Studio Practice, ed. A. Wallert, E. Hermens and M. F. J. Peek, The Getty Conservation Institute, Los Angeles California (1995) 38-47.

34 Pomaro, G., Il Recetario del Fondo Palatino della Biblioteca Nazionale Centrale di Firenze, Giunta Regionale Toscana, Editrice Bibliografica, Milano (1991).

35 Morgan, M., H., Vitruvius, The Ten Books on Architecture, Harvard University Press, Cambridge (1914).

36 Matthew, L. C., 'Vendecolori a Venezia. The reconstruction of a profession', The Burlington Magazine 144(1196) (2001) 680-686. 
Received: 2015-07-19

Revised: 2016-01-17

Accepted: 2016-01-18

Online: 2016-01-22

\section{(ब⿻ $\Theta$}

This work is licensed under the Creative Commons Attribution-NonCommercial-NoDerivatives 4.0 International License.

To view a copy of this license, visit http://creativecommons.org/licenses/by-nc-nd/4.0/deed.en. 